\title{
WARTIME METHODS OF DEALING WITH LABOR IN GREAT BRITAIN AND THE DOMINIONS
}

\author{
Margaret H. Schoenfrld* and Anice L. Whitney $†$
}

The British preference for voluntary action rather than compulsion in promoting industrial production has persisted throughout the present war. Although the Government has statutory powers to take any measures required in the interest of the war effort, controls have been introduced slowly and only when it became clear that the war effort was likely to be hampered if the voluntary machinery of employers and employees were not supplemented. Labor has been ready for the successive controls before they became effective and has sometimes urged their adoption. Worker representatives have participated in formulating the emergency laws and regulations. When necessary, collective agreements have been modified by joint action of employees to permit changes in wages and hours and other working conditions. In surrendering the gains acquired over many years the workers of Great Britain are making their contribution to hastening victory. In return they demand a better postwar world and the Government has already pledged restoration of trade practices that are temporarily waived.

Measures established in Great Britain have greatly influenced those of the Dominions-as, for example, in Australia, Canada, and New Zealand. However, timing of labor controls has varied considerably as have the rigor and scope of application. The degree of industrialization before the war, the organization of industry, and the political party in office partially account for developments. Nearness of the several countries to the theater of war has also been a factor in determining the speed of economic mobilization and changes in labor standards.

In Australia and New Zealand, countries that were not highly industrialized before the present war and which had an orderly procedure for determining working conditions by the arbitration courts, drastic powers over labor were not exercised until after Japan entered the war. Up to that time the major efforts of these two countries were directed toward supplying men to the Empire's armed forces in remote areas and butter, meats, wool, and other agricultural and pastoral products to Great Britain.

In Canada industrialization was intensified immediately with the outbreak of war

A.B., r9r8, A.M., 1920, George Washington University. Assistant Editor, Monthly Labor Review, United States Bureau of Labor Statistics.

+Mus.B., I899, Syracuse University. Associate Editor, Monthly Labor Review, United States Bureau of Labor Statistics. 
and members of the armed forces of the allied nations were sent into the country for training. To avert inflation as a result of greatly increased buying power curbs were placed on prices and wages in 1940 and strengthened in 194r. A basis for an all-out war effort through general conscription of manpower was not established until April 27, 1942, when the question of conscription for overseas service was favorably determined by plebiscite.

Great Britain's procedure has been still different. Staffing the war plant was paramount from the start. Up to late 1941 , when the building program of war plants was complete, labor shortages were often localized geographically and industrially and could be met by directing employees to transfer and maintaining those of special skills for particular industries. But in December I94I legislation was enacted providing for conscription of women as well as men for the auxiliary armed forces, civil defense or industry.

Methods adopted in Great Britain for dealing with wartime labor problems are described in some detail in this article, followed by résumés of the Australian, Canadian, and New Zealand machinery. ${ }^{\perp}$

\section{Great Britain}

Conditions differ greatly in this war from those of I9I4-I8, but nevertheless basic labor problems are the same. Therefore, Great Britain has made use of earlier as well as present experience in shaping labor policy. After Munich, plans were made to prevent a haphazard movement of skilled men from essential civilian tasks into the armed forces, which, if unchecked, would have seriously impaired capacity to produce military equipment and supplies. For the past two years apportionment of manpower remaining in civilian pursuits has involved careful planning to secure the maximum production from a relatively small population. Facilities have been established for training workers for jobs requiring higher skills and for bringing as many new workers, chiefly women, into industry as possible. It is imperative that plants once staffed shall be kept in operation and therefore new arbitration machinery was provided for in industrial disputes. Finally, checks have been placed on inflationary movements which follow when earnings rise and the volume of goods declines, and efforts have been made to prevent impairment of the workers' health and welfare under the necessarily abnormal conditions of employment.

\section{Allocation of Manpower}

When the voluntary national service campaign started early in 1939, the first schedule of reserved occupations was used in reserving from military service those men required to maintain war production. Men were then restricted in joining the armed forces in other than their regular trade or professional capacity and for service that would entail full-time duty in case of war. The first wartime schedule of

\footnotetext{
${ }^{2}$ No effort will be made to supply citations to the numerous statutes and orders to which reference, frequently by title, is made in the text. In a bibliographical note at the end of the article, references to the various source materials employed have been collected. As this article was prepared in the spring of I942 very recent labor developments are not covered.
} 
reserved occupations was issued in September 1939. Since that time the schedule has been amended frequently in the light of experience and the rapidly changing military and industrial needs. Early in the war, occupation and age determined whether a man would be reserved from service in the forces. In I941 a third factor was added, namely, whether the man performed work essential to the war effort. The schedule was revised again in December I94I to show the ages of reservation for reserved occupations as of the first of that month. Arrangements were being made to replace gradually the existing method of block reservation by occupations, by a system of individual deferment of calling up. Employees who are dereserved under the new plan and their employers have the opportunity of applying for deferment.

Power to apportion labor between war and other industries has been assumed under a series of laws and regulations of which the first was enacted August 24, x939. Under the Emergency Powers (Defense) Act of that date, the King was empowered to make defense regulations, by orders in council, for securing the public safety, the defense of the realm, the maintenance of public order, and the efficient prosecution of any war, and for maintaining supplies and services essential to the community. When the act was renewed a year later it was extended to provide for the issuance of orders in council requiring persons to place themselves, their services, and their property at the disposal of the Crown to the extent necessary for the same purposes. Power was also granted to amend legislation passed since the beginning of the war. The Emergency Powers Act was renewed again in the summer of r94x.

The successive enabling laws under which the Minister of Labor and National Service has directed persons to perform required services have had a profound effect on the utilization of labor. The r940 act was broader in scope than that of r939, but further power was thought needed to conscript women as well as men, and this led to passage of the National Service (No. 2) Act in mid-December r94r. Women were made liable for service in the armed forces, civil defense, and certain industries. They will not be required to handle lethal weapons, but may volunteer to do so. For the present, single women, between 20 to 30 years, will be called in that order. Married women are not to be conscripted but will continue to be directed into industry. Women having children under $\mathrm{r}_{4}$ years in their care are exempt.

At the same time the age for compulsory military service for men was raised from 40 to 50 , the intention being to place the older men in sedentary work to relieve younger men for combat duties. The minimum draft age for boys remains $\mathrm{r} 8$, but in the future boys will be called up at $181 / 2$ in place of 19 . Boys and girls between the ages of $x 6$ and 18 are required to register and will be interviewed to encourage them to join appropriate organizations. The minimum age for entry into the Home Guard was reduced to 16 for certain duties.

Growing labor shortages led to broadening the scope of the Emergency Powers Act when it was renewed on May 22, 1940, making it possible to "direct" workers into war work. The Undertakings (Restriction on Engagement) Order of June ro, I940, forbade employers to engage a worker or seek to engage one, except by report- 
ing to the labor office of the Ministry and engaging the worker it suggested. Restrictions were placed on engineering, building, and civil engineering, agricultural (male) workers, and coal-mining workers.

But it was not enough merely to facilitate the transfer of labor to war industries. Some measure was needed to prevent them from drifting back to the labor exchanges for new assignments. The answer to this need was the Essential Work (General Provisions) Order of March 5, I94I, which as applied prevents loss in production through unnecessary turnover of labor or absenteeism. Employers may not bid against each other for employees, and skyrocketing of wages is avoided. Application of the order to an industry is not automatic. It depends upon scheduling by the Minister of Labor of any enterprise which is engaged in "essential work" as defined in the order. Under an amendment specific classes or descriptions of persons may be scheduled instead of the entire enterprise. In a scheduled establishment employment is guaranteed under terms no less favorable than are fixed for the same kind of work by collective agreement. The management may discharge employees only for serious misconduct, and the employee's right to leave is strictly controlled and is, in general, subject to permission from a national service officer and at least one week's notice. An employee may be lent without permission for not to exceed 14 days. Unexcused absence is penalized.

In return the employee receives a guaranteed time-rate minimum wage. When work in his usual occupation is not available, however, he must be willing to do work he can reasonably be expected to perform. Appeals from assignments are allowable. The wage provisions of orders do not supersede more favorable terms of collective agreements.

Special groups were registered for employment before I94I, but on March I5, the Minister of Labor issued the Registration for Employment Order of I94I authorizing a survey of the available labor force in the country. Men with experience in specialized branches of employment such as marine engineering, Merchant Navy, and coal mining, have been registered at different times. Young women of specified ages have been ordered withdrawn from certain trades under the r94I order. Women in the retail distributive trades (other than food) between age 20 and 25 are affected, as are certain other occupational groups. Withdrawals from these retail trades are being pushed to the limit. The volume of trade is constantly shrinking, owing to shortages of materials for civilian use, and the Government took steps last November to license new establishments with the object of eventually reducing the number of retail outlets. On January I it became illegal to open a new shop or to sell new lines at existing shops without a Board of Trade license issued by the local priceregulation committees.

\section{New Sources of War Labor}

Labor obtained by exercise of the Government's compulsory powers was supplemented under a new scheme whereby a diversified group of civilian-goods industries 
were voluntarily concentrated and a part of the labor, machines, and materials were released for war orders. The plan was presented in March 1941, by the Board of Trade. Civilian-goods manufacture that is absolutely necessary was concentrated in a limited number of the more efficient plants in the respective industries. A plan was worked out whereby the establishments that continued to produce-known as nucleus plants-would provide a measure of compensation for those suffering loss of their business. The Government did not undertake to indemnify owners. As originally planned, the concentration was virtually completed in November and 144,000 workers and $45,000,000$ square feet of factory space were released for more important use.

Before the conscription act became law in December 194I, when women entered upon war work voluntarily and by direction, and, when they could not be called for the auxiliary military services or civil defense, the need for their services was widely publicized, the appeal being made on patriotic grounds.

Recognizing the difficulties confronting married women while doing war work, day nurseries were created in limited number for the care of children, hours of shops in some areas were adjusted to permit after-work marketing, and marketing was in some cases done by volunteer shoppers acting for several employed women. While helpful, these measures are on a small scale and would need to be greatly extended to fulfill a highly useful purpose. Extension of nursery facilities is often discussed in the House of Commons. Some plants have provided part-time employment for women who are unable to be away from their homes for a full day's work. The length of the work-week and the time of the shifts vary from plant to plant, but the plan has proven practicable and has gained support. Efforts are being made to greatly expand job opportunities of this kind.

Both the new entrants into industry and those previously employed at jobs requiring little skill have had the opportunity to secure training and the rates of pay for trainees have been made so attractive that there is no loss in earning power in the period of preparation for higher-grade employment.

From the beginning of the armament program the Government sought an agreement in the engineering industry for the dilution of labor to permit upgrading of the unskilled and women to work of higher skill, and to bring workers into the industry. As war approached, a voluntary agreement permitting dilution was reached on August 3r, I939. In May $194^{\circ}$ it was decided that women filling boys' and youths' jobs should receive the boys' or women's rate whichever was greater. Where women engaged in men's jobs they were to serve an 8-week probationary period at the women's national wage; at a higher rate for 12 weeks; and at a still higher rate for 12 more weeks. If they qualified at the end of 32 weeks they were to be paid the same as the men they replaced. A woman fully qualified for the man's job at the outset would not be required to serve a probationary period. There are indications that women are not replacing men in the same jobs at the same pay to a great extent as yet. 
The Government adopted a scheme in 1940 to expand its training facilities. The closest cooperation was developed between the centers and employers. Employers were encouraged to train workers in their own workshops. Instruction is given to persons with no skills and those having some skill who may thereby be upgraded. In some establishments women as well as men are taught. Employed persons are permitted to leave their jobs and enroll for training, if their jobs are not essential to the war effort. It was estimated in I94I that from 150,000 to 200,000 workers a year were passing through government centers. Even more are trained in private industry. Early in 1942 it was announced that the number of Government training centers was being reduced from 39 to 24 . While this entailed a reduction in activities it was stated that a better balance of training trades had been achieved.

Trainees are entitled to allowances from the Ministry of Labor, whether trained in government centers or in plants. Pay in plants may not exceed pay at government centers, and the men trained in the factories must be moved elsewhere when their courses are completed.

Changes in rates of pay of trainees, effective March $3^{\mathrm{I}}$, I94I, made their pay broadly equivalent to what they would have received if entering industry directly. Formerly, allowances were based on the expenses incurred during training. Now trainees are regarded as under contract of service and receive weekly wages. They are liable for health- and social-insurance contributions and are entitled to lodging allowances when away from home just as are other workers. The lodging allowance is $3^{\mathrm{s}}$. $6 \mathrm{~d}$. a night if the trainee continues to maintain a home in the area from which he came, but, if not, he is allowed the same sum daily for a period up to 7 days to help him settle in the new area. Fares are paid both ways if the trainee comes from a distance. Young trainees under Ig are given extra allowances for meals and in case of sickness.

A plan was adopted in I94I for training and resettling disabled persons of either sex over age 16 , regardless of the cause of disablement. Foreigners disabled since the war began are eligible, whether or not the disability is the result of enemy action. Courses are given in certain government centers, at institutions experienced in training the disabled, at technical colleges and schools, and in industrial establishments. The allowances for the disabled are lower than those for able-bodied trainees.

\section{Arbitration of Industrial $\dot{D}$ isputes}

Organized labor experienced a temporary loss of prestige after the general strike of 1926 and the enactment of the Trade Disputes and Trade-Unions Act of I927, forbidding unions to coerce the Government and outlawing sympathetic strikes. Once public confidence in the unions was restored they assumed new importance. A great deal of effective machinery for the settlement of industrial disputes established by joint arrangements of employers and employees was in operation at the beginning of the present conflict. For industries and trades that were not well organized, negotiation of industrial differences was possible with Government assistance. Con- 
ciliation, arbitration, and inquiry into disputes were provided for under the Conciliation Act of 1896 and the Industrial Courts Act of rgrg.

Strike activity in 1940 was at the lowest level in the nearly $5^{\circ}$ years of official British statistics. Nevertheless, an order in council was issued in July of that year granting the Minister of Labor power to issue orders designed to prevent the interruption of work and to provide for an arbitration tribunal.

Employer and employee representatives expressed the desire that as far as possible the existing joint machinery should be used to settle disputes. The arbitration order (I) provides for conciliation and arbitration; (2) prohibits strikes and lockouts unless the controversy has been reported to the Minister of Labor and National Service and has not been referred by him for settlement within three weeks from the date reported; (3) obligates employers in every district to observe terms and condi- tions arrived at by collective agreement or by arbitration; and (4) provides for recording departures from trade practices to facilitate the operation of legislation for their restoration after the war. Nothing in the order affects the Minister's power to refer trade disputes for settlement under the Industrial Courts Act of 1919, provided both parties consent.

A National Arbitration Tribunal was formed by the Minister of Labor, consisting of five members. One employer and one employee member were to be chosen from panels of employer and employee representatives. Originally three appointed members served full time, but this did not prove practicable. By an amendment of November 14, 194I, a panel of not more than five appointed members was ordered to be created by the Minister, of whom two in addition to the chairman may be selected to sit for any hearing before the tribunal.

Any agreement, decision, or award in a case referred by the Minister, whether reached by conciliation, joint negotiation, or the National Arbitration Tribunal, is binding upon the parties, and the terms of the settlement become implied in the contract between the employers and workers concerned.

While the strike record for $194 \mathrm{I}$ was not as good as in 1940 the aggregate number of working days idle owing to disputes was considerably lower than in any of the preceding Io years except I933 and 1934. There were 1,080,000 days of idleness in I94I as compared with $2,450,000$ in I916 and 5,900,000 in I918. Most of the cases referred to the new tribunal thus far have risen out of claims for wage increases. Some of the decisions, as for example, in the engineering, mining, and railroad industries, affect hundreds of thousands of employees. Under certain of the important awards the increases have been smaller than labor hoped for and under others any advance in wages was denied.

The Select Committee on National Expenditure in its twenty-first report quotes the view of the Conciliation Department of the Ministry of Labor "that, human nature being what it is, a certain number of stoppages are inevitable, and that the cessation of work may actually serve a useful purpose by bringing the parties to a full realization of the issues between them and, by forcing on them the necessity of 
making a serious effort to resolve them, may accelerate a settlement." The Committee agrees that there may be a large element of truth in this statement, but, though strikes may clear the air in peace time, "in time of war when the existence of the Nation is at stake it seems hard to justify this expensive form of ventilation."

\section{Gains and Losses for Labor}

British labor's surrender of mobility and free choice of occupation was preceded by a driving effort to raise war production by abandoning normal working schedules. Daily and weekly hours of work on war production were lengthened to the limit after the fall of France and the evacuation of Dunkirk. Holidays were canceled and vacations with pay were either given up or postponed during the summer. Workers were urged to work a 7-day week without adequate rest periods and schedules up to 12 hours daily and 84 hours weekly were observed in munition plants. Normal peacetime hours in most industries were 44,47 or 48 weekly.

Although the pace could not be maintained for long, a large volume of replacement was made for the guns, tanks, and other equipment lost on the Continent. This tremendous effort was made in response to a plea from the Minister of Labor in the newly established Churchill Government in May 1940. It was at this time that the wholehearted cooperation of labor was obtained. Previously, organized workers had refused cabinet office.

When the ill effects of overtime became pronounced, that is, in lowered productivity and increased absenteeism and illness, the Minister of Labor proposed a scheme for gradual reduction in working time under a system of rotation to a maximum of 55 or $5^{6}$ hours weekly. While hours worked are below the level of the summer of 1940 , there is further need for adjustment by the addition of more shift work and new employees. Sunday work, at higher overtime rates than are paid for weekday overtime, is especially opposed by the Select Committee on National Expenditure on the grounds that it raises costs of production unduly.

As the hours of men, except in specially hazardous occupations, are not limited by law, working time continues to be fixed by agreement of employers and workers. For women and young persons maximum hours were established under the Factories Act of 1937, but several orders have been issued during the war permitting extensions. The latest of these, adopted on January 23 , I942, permits women and young persons aged 16 or over to be employed 55 hours a week instead of 48 as provided by law; younger persons may work not more than 48 hours weekly in place of the 44 hours specified by law effective on July $x$, I938. Authorization for the extension of hours may be given by factory inspectors. An order for the pottery industry, promulgated a month earlier, established a 53-hour maximum. In both cases the change was made with reluctance and only because of the acute war need.

A special body-the Industrial Health Research Board-deals with the problem of maximum production in relation to the health and efficiency of the workers. In its second report giving the results of an investigation of conditions in munition factories 
from the outbreak of war to the end of June I94I the Board concludes that time lost by factory workers through sickness, injury, and absence without permission tends to vary with the weekly hours of work. It was usually low when the weekly hours were less than 60 but rose as the hours increased up to 75 . Over an extended period weekly hours not to exceed 60 to 65 for men and 55 to 60 for women were suggested on the basis of the findings. Although it was not possible to maintain the high level of productivity obtained in the spurt after the fall of France output had remained higher than in the previous period in nearly every case.

Women, on the whole, lost more time than men. Domestic responsibilities were an important cause. Time-keeping by factory personnel was deserving of praise, in the opinion of the Board, considering the difficulties of transport and the losses of homes, working time, and rest owing to air raids. It was not possible to measure exactly the time loss because of sickness, injury, and absence without leave but it tended to increase as the war continued. The average time loss from these causes was $7.5 \%$ and for absence without permission alone, $3.7 \%$.

Money wages are higher in Great Britain than at any previous time. Rates of pay have advanced and there is full employment with a great deal of overtime worked at rates above the normal hourly pay. Many families have more than one wage earner now that all able-bodied persons are urged to work, but in families where the chief breadwinner is in the armed services the family income is likely to have shrunk. According to a government survey for 16 manufacturing and nonmanufacturing industries in Great Britain and Northern Ireland, weighted average weekly earnings were 75s. rod. in the week ended July 12, 1941. This was an increase of $42.4 \%$ over the last pay week of October 1938. Men's earnings rose by approximately the same amount (44.1\%) from 1938 to I94I as those of all workers $(42.4 \%)$. The most striking advance was that of youths and boys $(60.7 \%)$, as a result of which their average weekly earnings in July 194I (4Is. Ird.) were within 2 shillings of women's earnings (43s. IId.). Women's and girls' earnings rose only $35.1 \%$.

In transferring male and female workers the Government has tried to prevent financial loss to them by making special allowances, administered by the Minister of Labor. Payment of a lodging allowance may be made to a married man sent to a new area as long as he maintains his home in the area from which he came. A "settling-in" grant may be made if the worker does not receive the lodging allowance. Women receive an extra sum at the end of the second week of employment. A "continuing liability" allowance is provided for persons who, having taken their families to the new location, are not eligible for the lodging allowance. This is to aid them in meeting rent, taxes, mortgage interest, or furniture storage in the old area, when they are unable to terminate liabilities before being transferred. Workers qualifying for the "continuing liability" allowance are granted the right to obtain transportation fares for their dependents. This is in addition to the free travel warrant the worker obtains for the first journey to the new place of work and the payment for travel time if it lasts over 4 hours. 
Transferred workers may borrow up to $\oint_{\mathrm{I}}$ from the employment exchange on reaching the new area, repayable out of the first week's pay. Government aid is given in moving the workman's family and furniture if it appears he will remain in the new location long enough and the move is desirable.

A positive national wage policy has not been adopted. Concern was expressed by the Government in 194I lest the steady upward trend of wages contribute toward inflation, now that civilian goods are restricted in quantity. It sought the adoption of a plan that would permit wage rises in meritorious cases where inequities exist but would stop general increases. In answer the Trades Union Congress held that some inflation is inevitable in wartime and that any serious attempt to solve the problem should begin by curtailing working time, thus increasing productivity and benefiting the health and well-being of labor while lowering workers' incomes by reducing the volume of work at overtime pay. At the same time further price controls, rationing, control of profits, and lending of savings to the Government were advocated.

Price controls and rationing have not stopped price rises, but the rate of increase was far smaller in I94I than in 1940. Controls consist of centralized purchase of imported foodstuffs, limitations on distributors margins and retail selling prices, and direct subsidy of certain articles of food. Clothing, many important foodstuffs, and soap are rationed.

Cost of living as measured by the official index numbers, using July Igr4 as a base of roo, rose approximately $29 \%$ from September 1939 to January I942-from 155 to 200 . Of the 45 -point rise, $23 / 4$ points represent the effect of increased taxes on sugar, tobacco, and cigarettes, and matches, and some 6 points resulted from the sales tax. Throughout x94I the index ranged within a 5-point limit of rg6 to 20I. It was 200 in January 1942. Rents have been kept stable throughout the war by rentrestriction legislation; foods advanced over one sixth; fuel and light over one fourth; other items nearly one third; and clothing nearly doubled in price.

\section{Enforcement and Administration}

Enforcement of wartime legislation and regulations has not been a serious problem for the Government. There have been some illegal strikes, resulting in sentences for those responsible. In the recruitment and transfer of workers the Ministry of Labor followed the policy of securing voluntary action. It was necessary to direct persons into jobs only in exceptional cases and up to the middle of I94I there had been only 32 prosecutions of which 29 were decided in the Government's favor. The policing necessary under the essential-work orders has been carried on within industry. Where employees wish to appeal employer decisions they have recourse to government machinery but there is no intent to interfere with joint employeremployee arrangements.

Knowledge that worker representatives participate in the formulation and execution of war policies stimulates labor in its war efforts. Far greater responsibility has been placed upon the Minister of Labor than in the last war. The office was redesig- 
nated as the Ministry of Labor and National Service in September 1939. A labor representative, who became Minister in May 1940, when Prime Minister Chamberlain was forced out and the Labor Party agreed to join the Government, has continued in this post since. Powers of other government departments, as, for example, under the Factories Act, were assigned to the Ministry for the duration of the war. The labor exchanges are the key for the clearance of workers and the expansion of the Ministry has been built about them.

Committees representing organized employers and employees advise the Minister of Labor and there are similar committees for regional boards and other government departments. Before the Minister of Production was appointed early in 1942, absorbing the duties of the Production Executive, the Production Executive and its regional boards had advisory committees of employers and workers. Thus, both parties to industry have the opportunitiy of expressing their views on policies in the making and may secure adjustments that will prevent untold difficulties in carrying out production and other plans. With government approval joint production advisory committees are now being formed in individual plants to encourage increased output.

\section{Dominion War Measures}

Whether the basic war legislation was enacted by the British Parliament for the possessions, or by the Dominions to apply within their own territories, the emergency powers of the early war period were similar to those applied in the British Isles themselves. Both Australia and New Zealand adopted emergency powers acts in 1939 which were later extended. In Canada the War Measures Act of 1914 enabled the Government to take the immediate measures needed in organizing the war effort and new legislation was not enacted until 1940. As Australia, Canada, and New Zealand, the countries for which labor measures are described, were not highly industrialized as compared with Great Britain at the outbreak of war, the training of workers and erection of war plants raised acute problems. All three countries were large exporters of raw materials or pastoral products and prior to hostilities depended upon imports of many manufactured goods.

\section{Australia}

The National Security Act providing for the safety and defense of the Commonwealth of Australia and its Territories was passed in September 1939 and amended in June 1940. The act empowered the Governor-General to make regulations covering specific conditions relating to the public safety and defense. The amendment authorized the issuance of regulations "requiring persons to place themselves, their services, and their property at the disposal of the Commonwealth," although any form of compulsory service beyond the limits of Australia could not be imposed. No form of compulsory naval, military, or air-force service could be required, nor any form of industrial conscription.

As a result of the growing seriousness of the war situation in the Southwest Pacific, new manpower regulations were put in effect by the Australian Government 
early in February 1942, providing for stabilization of prices and individual wages and wage rates for industries. Wages may not be raised from existing levels, but the arbitration court and other wage-fixing tribunals may permit the completion of existing negotiations and wage adjustments. Adjustment of wages to the cost of living will be continued. All employment must be obtained through government labor bureaus and no employee may change to a new job in any type of work, whether protected or not, unless the prospective employer has the sanction of the national service office. Arbitrary dismissal of employees essential to industries is prohibited. Drastic penalties are imposed on persons absent from work except for prescribed reasons (such as sickness).

All men between the ages of $\mathrm{x} 6$ and 60 were required to register in April I942 and there is compulsory organization of men in labor units for urgent war work. In the public interest the Prime Minister may direct any person, either individually, collectively, or sectionally, to perform any service or duties of which he is capable.

Australia's first list of reserved occupations exempting men from military service, issued in November I940, classified occupations under three main heads-those of direct importance to war, those of importance for munitions or essential commodities and services for the troops and civilian population, and those in which skills can be converted readily to use on war work. Control over the issuance of certificates of reservation was vested in a central manpower committee and subordinate officers. Reservation was extended to all branches of the armed services and prevented men affected from enlisting or being called, except in their technical or trade capacity. The list has been under continuous review.

Prior to the new manpower regulations the labor force of munitions industries was protected. The National Security (Employment) Regulations of r940 forbade an employer not engaged in producing or reconditioning munitions to hire, without a special permit, any employee in the metal and the motor-vehicle trades. Partly to restrict competitive bidding among employers in these industries, employers were prohibited from paying skilled employees engaged in munitions manufacture or plant maintenance a higher or lower marginal rate of pay above the basic wage than is specified in regulations. However, "merit money" and special allowances granted under an award could be continued.

At the outbreak of war there was a particular shortage of fitters, turners, machinists, and tool and pattern makers. A survey of the country's facilities for training and retraining workers was made almost immediately with the view of developing short and intensive training courses. Power having been given to the Minister of Labor to make training arrangements, it was decided to use the technical-education schools by expanding their capacity. Workers were taken into the schools in larger numbers to be trained both for the armed forces-particularly for ground work with the air force -and for essential industries. The courses provided for instruction of persons with no previous knowledge of engineering work or munitions manufacture and for upgrading of workers with some skill. By the end of 1940 about $15^{\circ}$ technical colleges 
were giving courses lasting about 8 weeks, with 40 to 48 hours of instruction per week. Men and boys 16 years of age and over and women of 18 and over are eligible. Trainees qualifying as munitions workers are paid the basic wage for a 44-hour week, and work day and night shifts in alternate weeks.

The creation of the Federal Department of Labor and National Service in 1940 facilitated the extension of the plans for technical training, as branch administrations were established in the states to help solve problems involved. Some difficulty was met at first in expanding the apprenticeship program, as the trade-unions objected to any unnecessary increase in apprentice training and to any relaxation of apprenticeship standards.

Dilution of skilled labor has been carried out by agreement between the Commonwealth Government and the organizations of employers and workers concerned. Power to arrange for the training of munition workers was first vested in the Minister for Supply, then in the Department of Munitions, and subsequently in the new Department of Labor and National Service.

In I940 the Government and representatives of the munitions industries agreed that all competent tradesmen should have preference in employment regardless of age, and that no recognized tradesman might be discharged for lack of work while any tradesman brought in under these agreements remained in employment. When skilled labor becomes available the original trade practices must be restored. Registers of all added tradesmen must be kept and particulars supplied to the union and the employers' organization concerned. The schemes are administered by central committees representing the Government, employers, and trade-unions, and by tripartite local committees working under the central committees.

The agreements did not apply to women, but their application to women in engineering has been discussed. In May I94I about 700,000 of the approximately 3 million Australian "breadwinners" were women. Arbitrary lines have often been drawn between men's and women's work and rates of pay have been lower, in general, for women. The expanding munitions industries together with the growing scarcity of men led to a great increase in women workers. Some union leaders stated that they would not oppose the employment of women if they were paid the same rates as men. After Pearl Harbor plans went into effect to replace $30 \%$ of all aircraft workers by women, as the Government moved to double aircraft production as the principal national necessity. As of March 2, 1942, a regulation provided for the employment of any female on munitions work at rates to be determined by the Ministers of Munitions and Aircraft.

Since passage of the Commonwealth arbitration law in 1904, interstate questions of wages, hours, and working conditions have been established by award of the Court of Conciliation and Arbitration. As the National Security (Industrial Peace) Regulations of I940 removed the provision limiting awards by the Commonwealth Court to interstate cases, it may now declare that any rule, regulation, etc., in any award or order shall be a common rule of any industry in which a dispute arises, or of any 
part of that industry, or of any group of industries of which that industry is one. Such an award is binding to the extent declared by the Court.

The Commonwealth law in Australia outlaws strikes for persons covered by existing awards or agreements. In the pre-war period the labor legislation of all but one state in Australia limited the right to strike. Yet the number of man-days idle owing to strikes averaged 660,000 annually from 1935 to 1939 . In 1940 strikes involving 192,597 work-people resulted in a loss of 1,507,252 working days. As a means of strike prevention the war regulations provide that the Arbitration Court may determine a matter in dispute even though no strike has occurred.

The Conciliation and Arbitration Court may set rates of wages and hours in pursuance of its function of preventing and settling industrial disputes. The basic wage fixed by the Court is composed of two parts-the "needs" basic wage and the "prosperity loading." The former is periodically adjusted as changes occur in the cost of living and varies according to locality. Variations in the "loading additions" depend upon the rise and fall of prosperity. The Court also establishes secondary rates for certain categories of unskilled workers and semiskilled and skilled labor.

Working hours are fixed by the Court under its general powers in all of its awards. The 44-hour week is the prevailing maximum under awards. The weighted average working hours a week for all Australian industries, exclusive of shipping and rural pursuits, was approximately 45 in I94I. Owing to the seriousness of the situation a large amount of overtime work is being performed at rates of pay above the normal.

Operation of the Australian industrial system. depends very largely upon the organization of workers in trade-unions and employers in associations. While the Supply and Development Act of 1939 empowered the Government to regulate the establishment, maintenance, or operation of factories for the supply of munitions, it did not deprive a trade-union or member of any rights accorded by earlier legislation. Under the sweeping regulations now in effect these rights are in abeyance.

Labor has shared in the administration of the Government's war policy. Its position was strengthened when a Labor Government was placed in power in September 194I. Representatives of labor are included in advisory state committees on price control and on the state area boards of management created by the Department of Munitions. More significant, however, as examples of joint control are the labordilution agreements made by the Government, employers, and unions in certain trades. A Trade Union Advisory Panel was formed in July r940 to advise the Government as to industrial and employment conditions, and in July r94I labor was represented on the new Manpower Priority Board.

The high level of employment in r940 was reflected in demands for wage increases. Special "war loadings" were added to workers' wages but the 1942 manpower regulations put a stop to pay advances for the duration of the war.

Commodity price control has been gradually extended since the outbreak of war. It has been highly successful and has met with less resistance than some of the other 
economic measures. The only commodity rationed for civilian use up to April 1942 was Ceylon tea.

\section{Canada}

In Canada the earliest steps for the organization of the country for war were taken under the War Measures Act of rgr4. Three measures of particular importance to labor were adopted in 1940. On June 21 the Canadian National Resources Mobilization Act required persons to place themselves, their services and property at the disposal of the Crown for the defense of the country and the prosecution of the war. These powers did not require armed service outside the territorial limits of Canada. The Department of National War Service Act of July I2 provided for such a Department, under the Minister of Agriculture. Its duties were to register the population and to promote voluntary organization and coordination of the war effort. By order in council of July 2 the Wartime Industries Control Board was set up and provision made for controllers for the leading industries. This body was charged with organizing the sources of supply of munitions and mobilizing economic and industrial facilities as related to munitions.

From the outset of war the Canadian Government placed its main emphasis upon price control. A Wartime Prices and Trade Board was established by order in council of September 3, r939 under the authority of the 1914 Act. Its action prevented buyers' panic, speculation, runaway prices, and rent rises early in the war. Other governmental agencies also operated in the price field, and a sweeping order was promulgated on August 29, I94I, centralizing control over prices in the Wartime Prices and Trade Board. The Board may prescribe conditions of sale of any goods or services, fix quantities to be bought or sold, and license handlers of foods, feeds, clothing, millinery, footwear, and furs, and cancel or suspend licenses. Provision was also made for unifying control over war industries under the Wartime Prices and Trade Board and also the Wartime Industries Control Board. Thus, the general price-fixing body shares in regulating war industries.

By the Price Ceiling Order effective December I, I94I prices were limited to the maximum in the base period of 4 weeks from September I5 to October II, 194I, inclusive. Civilian rationing of sugar was introduced in January 1942 and of gasoline on April r. Originally the sugar scheme was operated under an honor system and later subjected to coupon rationing.

A wage policy was formulated by order in council of December 16,1940 to guide the various Canadian conciliation boards in establishing cost-of-living bonuses. An order of wider scope was issued on October 24, I94I, designed to supplement the Government's anti-inflation policy without imposing undue hardship on wage earners. It provided that basic wage rates were to be frozen at the level of November 15, except that unduly low or high rates could be brought into line with prevailing rates for the same or similar occupations.

At the same time all employers not specifically exempt were ordered to pay a cost-of-living bonus on basic wage rates, calculated according to changes in the official 
index of cost of living. The bonus may not raise wages above prevailing levels and is subject to the employer's ability to pay. August I939 was made the base period of I00 and for every rise or fall of I point employers were required to adjust the cost-ofliving bonus. For each quarterly point of change the adjustment is 25 cents a week for adult males and for others earning $\$ 25$ a week and over. For females earning less than $\$ 25$ weekly and males under the age of $2 \mathrm{I}$ the adjustment amounts to I percent of the basic weekly wage.

Originally small establishments were excluded, but an order of December 5, I94I extended application of the cost-of-living bonus to employers of one or more. Employees of Federal and Provincial Governments and municipalities were exempt. Cost-of-living bonuses for salaried workers were provided by separate order.

According to preliminary figures issued by the Department of Labor the increase in wage rates from 1939 to 1941 ranged from $8.1 \%$ in the building trades to $13.7 \%$ in the metal trades and in logging and sawmilling, while the rise for common factory labor was $\mathbf{1 5 . 6}$ percent. The official index of cost of living-using 1935-39 as a base of 100-was I0I.5 in 1939 and II5.4 in January I942.

Limitations on working hours imposed by the Fair Wages and Hours of Labor Act were removed on August 15, 1940. The 8-hour day and 48-hour week were suspended in building construction and defense projects in specified localities and the Minister of National Defense was authorized to extend suspensions to other localities. Long hours are prevalent. In mid-March 1942 the Minister of Labor urged that industrial operations be placed on a 7-day basis but with proper rest periods for the workers.

Before the war started a study of reserved occupations had been made by an interdepartmental committee. Soon after the declaration of war recruiting officials were directed by the Department of National Defense not to enlist skilled tradesmen except to the extent required in their particular trade capacity. Persons employed in the essential services of Canada were also exempted.

The supply of men for military duty was insured by new regulations effective March 23, I942, under which males aged I7 to 45 years, inclusive, who are physically fit for military service, were restricted from entering nonessential work or work that could be satisfactorily done by women or older men. Men may be released from agriculture for military service under order of the same date but may not enter nonagricultural employment. Written permission from a national service officer is necessary if an essential agricultural worker is to leave the industry.

Control over labor has been limited largely in connection with conscription for the military services within Canada and regulation of prices and wages. Compulsory overseas services, referred to the voters in a plebiscite held on April 27, 1942, was voted by a large majority. While the right thus acquired may not be exercised immediately-owing to the high rate of voluntary enlistment-the Government now has authority for any future action leading to complete mobilization of manpower.

Under the Industrial Disputes Investigation Act of 1907 as amended prior to the 
war, 30 days notice of proposed changes in working conditions was required; strikes and lockouts are illegal pending referral of a dispute to a joint conciliation board and a report from the Minister of Labor; and awards are not binding except by previous agreement of the parties concerned. Application was limited to mines, transport and communication, and certain other public utilities. Except in British Columbia and Prince Edward Island the Provinces gave the Dominion jurisdiction over disputes in these industries.

Amendments to the disputes law made in 1939 and r941 extended coverage to defense projects and all industries producing munitions and war supplies and made changes to improve its operation. In late $x 94 \mathrm{x}$ other amendments provided that a strike could not be called unless all the workers involved had the opportunity to consider it. Strikes were restricted even after a board of conciliation had presented its finding. Labor was required to report a proposed strike to the Minister of Labor who can, in his discretion, require a strike vote among the union membership. Majority approval is necessary.

Days of idleness through industrial disputes aggregated $3{ }^{19} 9,466$ in $194 \mathrm{r}$ as compared with 266,318 in 1940, 224,588 in 1939, and 886,393 in the peak year, 1937.

Since there is no general mobilization of manpower order, labor is placed by a number of devices. As a guide to placement a register of skills was established through registration of the population aged 16 years and over in August 1940. Workers covered by the Industrial Disputes Act and persons of designated and scarce skills may not be enticed from their employment by other employers. The labor force has been augmented by women. They are performing work formerly done by men in some cases. Their proportion in the total labor forces ranges from 3 to $60 \%$ in the different war industries. To encourage the transfer of labor to a point where it is most needed, transfer allowances were authorized by order of August 13, 194x. Loans up to \$10 may also be made to meet expenses during the first week following any change. Trainees for war industry have been supplied by the Federal-Provincial youth training program which was altered to meet the emergency and through special training facilities set up by the Dominion Government.

Trade-union membership is relatively small in Canada. There is no central federation as some unions belong to the American international organizations, others are independent, and some are grouped on the basis of religious affiliation. Organized workers in Canada are not in full accord with the various labor controls, although wholehearted support of the war effort has been pledged. A major reason for dissatisfaction is the operation of the machinery of arbitration and conciliation and a review of the terms of the law is sought. Free negotiation between employers and employees has been advocated in fixing wages and disapproval expressed with the wage freezing orders which labor believes should not have been made without consulting the workers and obtaining Parliamentary approval. 


\section{New Zealand}

When New Zealand entered the present war, industry was operating under a statutory 40-hour workweek, and wages were established under the arbitration system operative since 1894 . Arbitration of industrial disputes was compulsory, as was also union membership for workers over i 8 years of age receiving the minimum rate of pay for adults under an award or industrial agreement. At the beginning of the war, a labor government had been in office 4 years. It has continued without interruption for a total of nearly 7 years. New Zealand moved toward industrial rationalization and industrial planning, with the enactment of the Industrial Efficiency Act in 1936. The Bureau of Industry, which administers this law, recommends changes in the organization of industry, the standardization of materials, processes, and products; the training and supply of workers; the marketing of products and the purchasing of materials; and issues licenses to industries to operate. A person may be prohibited from engaging in any industry without a license, an industry covered by such an order being known as a "licensed industry." In passing upon applications for licenses special consideration is given to existing and future demands for the product, avoidance of surplus plant and capital, and the experience and capabilities of the applicant. The final objective is to formulate an industrial plan for the organization of an entire industry or related industries, establishing fair trade practices as was done under NRA codes in the United States.

Service in the militia in time of war was required of male persons between the ages of 17 and 55 years, prior to the present conflict. An order in council of June $\mathrm{r} 8$, I940, issued under the National Service Emergency Regulations of r940 under authority of the Emergency Regulations Act of 1939, made national service obligatory for all residents of New Zealand over 16 years of age, regardless of sex, and governs the conditions under which they may be called for service in the national interest. The Minister of National Service was empowered to direct any person covered to perform work of national importance in New Zealand. The terms of pay and conditions of work were to be the same as were applicable to similar work under laws, regulations, awards, or industrial agreements; or, if provisions were absent, they were to be established by the Minister of Labor. Persons called for work under these regulations were required to notify the Director of National Service if they ceased to be engaged in any essential occupation or if they changed employers or ceased to be employed. Employers were also required to give notice of changes.

More extensive authority to alter conditions of employment was also granted by order in council of June I8, I940. The Minister of Labor was granted power to suspend by published order the provisions relating to conditions of employment of any act or regulations, or of any award or agreement under the Industrial Conciliation and Arbitration Act of r925, or of any agreement under the Labor Disputes Investigation Act of $\mathrm{IgI}^{\mathrm{I}} 3$, or of any voluntary agreement. The Minister may prescribe substitute conditions of employment. 
The National Emergency Regulations of 1940 were amended in May r94I, extending the powers of the Minister of National Service to include the direction of individuals into training for any work or service in the national interest; the control over employment to prevent the hiring of specified workers; and the registration of employers and workers in specified industries or occupations.

By an amendment (No. 8, 1942) of the National Service Emergency Regulations of 1940, effective January 13, 1942, the Minister of National Service was accorded power to control manpower in essential industries as soon as he declares them to be essential. Two objectives are aimed at-conservation of labor in essential industries and mobilization of additional labor resources.

District manpower officers must give written consent before employment may be terminated by either employer or employee. It is not intended to stop all movements of labor in essential industries; the purpose is to keep it at a minimum, thus giving industry the greatest possible stability. The free flow of workers into essential industries will be permitted, but movement out will be subject to review. Registration of the entire population may be required. In announcing the regulations the Prime Minister of New Zealand stated that it was necessary to make heavy withdrawals of men for defense purposes, while imposing further demands on war production industries. Even in essential industries key men called up for military service must obtain postponement by appeal to boards and committees.

New Zealand used a list of reserved occupations for deferring or exempting workers from military service to continue to perform vital civilian work. Individual appeals have been dealt with on their merits, and no occupation has been completely or permanently reserved. Joint local manpower committees were empowered to hear deferment cases and could refuse a man to the military service but could not prevent him from giving up his job. The Industrial Conciliation and Arbitration Act of New Zealand was amended on July 18, 1939. Additional penalties were imposed on unions, employers, or workers for participating in work stoppages violating the provision for compulsory arbitration of industrial disputes. By registering with the Government, unions accepted the principle of compulsory arbitration, and the amended law empowers the Minister of Labor to cancel the registration of the union or an award or industrial agreement relating to it, if he is satisfied that a work stoppage will cause serious loss or inconvenience. Workers were also barred from protection of compulsory union membership in the future if their registration was canceled. Formerly fines were imposed on unions or individuals for participating in illegal strikes or lockouts but they were difficult to collect.

Emergency anti-strike regulations were promulgated in October 1939. Work stoppages and inciting other persons to strike are offenses against the regulations. In industries covered by award or agreements, machinery maintained for this purpose is to be invoked in settling matters in dispute. The Minister of Labor may name an emergency disputes committee of seven members to handle other disputes. In either case the decision is final. 
In the first 9 months of 1939 there were 6r strikes in New Zealand, involving 12,747 workers. The average duration of strikes was 3.24 days and the days of idleness resulting aggregated 24,020 . For the same period in 1940 the number of strikes was 44 , the number of workers involved 8,709, the average duration of strikes 8.13 days, and the days of idleness totaled 19,667. Strike activity in January to September I94I was at a higher level than in each of seven calendar years during the period 1926 through r940. Coal mining occupied first place in number of disputes, workers involved, and days idle.

In meeting the shortage of skilled labor the usual devices were resorted to, that is, shortening the terms of apprenticeship and vocational-training programs and providing special courses in technical schools and colleges. The Government, to make possible the rapid and intensive training of large numbers of additional workers, adopted the Auxiliary Workers' Training Emergency Regulations of $194 \times$ (No. 23) under the Emergency Regulations Act of 1939. The order authorized the Minister of Labor to appoint a council, composed of employer, worker, and Government members, to formulate and execute plans for training.

Persons trained under the Government scheme are classed as auxiliary workers and "shall not be engaged whilst there is a qualified worker in the same class out of employment on the register of the local union, and no qualified worker shall be dismissed merely by reason of the fact that an auxiliary worker has been engaged." Progress was reported by the Minister of Labor in June r94r. Classes had then been established in each of the chief centers in New Zealand to train workers for the munitions and engineering industries. Workers were not recommended to employers unless they had had $\mathrm{I} 6$ weeks of training. Selectees for training must be over $2 \mathrm{I}$ years of age and either ineligible for military service or married and with one or more children.

Training for national service is under the authority of the Minister of National Service, who was empowered by regulation of May I4, I94I, to direct any person to undergo training fitting him for such service. The Minister may prevent employers in specified industries from attempting to engage a worker except through a placement officer; may prevent workers from obtaining employment without approval of a placement officer; and may prevent employers from obtaining certain classes of workers.

Under the emergency powers, minimum rates of pay may be varied as required. A similar exception was made in I9I8-23 and again in 193I-32. Normally the Court of Arbitration cannot vary wages during the terms of awards. Although the Court has granted increases in minimum wages since the outbreak of war, support has been sought from organized employers and workers in keeping wages stable. An Economic Stabilization Conference, called by the Prime Minister in I940, recommended a pay-as-you-go policy and an increase in production as the keystone. Stabilization of prices and wages was also endorsed by the Federation of Labor at its 194I session. While it has not been possible to maintain prices at pre-war levels, profit 
margins per unit have been fixed at those levels under the price-control regulations adopted September I, x939. Prices as of that date must be maintained unless prior consent to the change is given by the Price Investigation Tribunal. Hoarding of goods is forbidden. The Tribunal's functions were later broadened to issue price orders and, generally, to oversee the price situation. Effective September I, I94I, the prices of essential foodstuffs, standard articles of clothing and footwear, and public services were fixed.

Official index numbers show that weekly money wages of adult males advanced from an index of $\mathrm{I}, \mathrm{IOO}$ in $\mathrm{I} 939$ to $\mathrm{I}, \mathrm{I} 30$ in $\mathrm{I} 940$ and $\mathrm{I}, \mathrm{I} 70$ in $\mathrm{I} 94 \mathrm{I}$. The retail price index was 990 in $1939, \mathrm{r}, 035$ in 1940 , and 1,072 in 1941 . Both sets of indexes are based on the average of $x 926-30$ as $x, 000$.

The provision of 1936 that the 40 -hour workweek should be the maximum under awards and agreements in industry except where employers could show cause for exemption was waived by a defense regulation in September 1939. At the conference of the New Zealand Federation of Labor in April I94I, an application from the New Zealand Employers' Federation for a general extension of statutory hours to 44 from 40 was refused. The Federation would not agree to any general extension of hours but agreed to continue to lengthen working hours when essential.

In January I942, after Japan entered the war, an Ir-hour 7-day week was being worked in key munition factories in New Zealand. In machine shops, where continuous and exacting work was beginning to tell on some of the men, hours were being reduced to 72 a week.

With the lengthening of working hours it became necessary to adjust overtime rates of pay. The Overtime and Holidays Labor Legislation Suspension Order of December I\%, I94I provided that overtime rates of pay should be one and one-half times the regular rate up to 4 hours daily ( 3 hours on any day for which it is provided by agreement) and 16 hours weekly (I2 hours where the 3 -hour limit applies). Double time is payable thereafter and for work on holidays. Payment at double the ordinary rate on special holidays was substituted for the treble-pay rate previously in effect. The Minister of Labor stated that in normal times special holidays and overtime rates had been fixed as a penalty to restrict work which is now necessary.

Under the Factory Industries Labor Legislation Suspension Order of December I8, I94x, the provisions of factory legislation, awards, and agreements were waived insofar as they operate to restrict work of women and boys in factories. Women and boys may not work more than $\mathrm{I} 2$ hours of overtime in any week.

\section{BIBLIOGRAPHICAL NOTE}

Australia: Digest of War Legislation in Australia, September 1939 to May 194 (Butterworth \& Co. Ltd., Sydney); Australian Official Handbook, 1941 (Australian National Publicity Ass'n, Melbourne); Quarterly Summary of Australian Statistics (Canberra) March I94I; New South Wales Gazette, 1940-41, various issues; Australian News ind Information Bureau, Australia (New York, Oct. I941 and Jan. 1942). 
Canada: Privy Council: Orders in Council, r939-42; Department of Labor: The Labor GazerTe, various issues.

Great Britain: Parliament: House of Commons, Debates, Dec. 2, 4, and 9, I94I and Jan. 20, 1942, Select Committee on National Expenditures, various issues; Ministry of Labour and National Service: MrNISTRY of LABour GazetTE, I939-4I, Hours of Work and Maximum OUtPut (July 25, I940), and HandBOoK, I94r; Hours of Work, Lost Time and Labor Wastage, Industrial Health Research Board, Emergencx Rep. No. 2 (I942); British Library of Information, Bulletins from Britain, No. 73 (New York, I942).

New Zealand: Official Yearbook, I941; Statutory Regulations, 1939-41; and Census and Statistics Departanent, Abstract of Statistics.

United States: Bureau of Labor Statistics, Monthry LABOR Review, r939-42; unpublished manuscript on labor in Canada after two years of war, by Mary T. Waggaman; and Bureau of Foreign and Domestic Commerce, Foreign Commerce WeErLY, various issues.

International Labor Office: Labor Supply and National Defense, Studies AND Reports, Serres C, No. 23 (Montreal, I94x); Yearbook, I939-40 (Geneva, I940); InternaTIONAL LABOR REvIEW, various issues.

Unofficial: Economist (London) various issues; Biddle, The Mobilization of the Home Front (Am. Public Welfare Ass'n, Chicago, r942). 